\title{
KAISAR AMERIKA DI NEGERI SAKURA : PERANAN DOUGLAS MACARTHUR DALAM REKONSTRUKSI JEPANG PASCA PERANG DUNIA II
}

\author{
Oleh: \\ Ginanjar Setia Mulyana, Agus Mulyana, Leli Yulifar ${ }^{1}$
}

\begin{abstract}
The main purpose of this research is to describe the Role of Douglas MacArthur in the Reconstruction of Japan after World War II in 1945-1951. Historical method is being used in this research paper, the method consists of : heuristic, critic, interpretation, and historiography. While the main topic of this research is how is the role of Douglas MacArthur in the reconstruction of Japan after World War II. Since he was appointed as SCAP in Japan by president Truman, with the supreme authority more than the Emperor himself, the U.S military officer made many reconstructive policies for Japan which was U.S main enemy of the Pacific War. With so many critics threw upon him from the Western countries, MacArthur rebuilt Japan from the political and economical sector with some changes especially liberalism and democratic view. The purpose of the reconstruction in to make Japan as the same side with the United States in the middle of Cold War with Soviet Union.
\end{abstract}

Keywords : Reconstruction of Japan, Cold War in Asia, SCAP

\section{PENDAHULUAN}

Jepang merupakan salahsatu negara dengan kekuatan ekonomi terbesar di dunia bahkan bisa saja disejajarkan dengan negara-negara maju seperti Amerika Serikat atau negara-negara di benua Eropa dan sudah tidak diragukan lagu bahwa Jepang merupakan salahsatu negara maju di benua Asia. Bila kita mengingat atau membicarakan Jepang, maka hampir selalu yang dibayangkan adalah negara modern serta memiliki penduduk yang memiliki tingkat kedisiplinan tinggi, kaya dan juga maju.
Jepang awal yang berasal dari penampatan pulau-pulau utama tersebut oleh suku Yamato, periode feodalisme yang melahirkan sistem klan-klan samurai, masa pemerintahan shogun yang berujung pada diberlakukannya politik isolasi di Jepang yang berakhir pada Restorasi Meiji tahun 1868. Restorasi ini membuka Jepang untuk pertama kalinya pada dunia demi mengejar ketertinggalannya pada dunia selama politik isolasi diberlakukan (Rosidi, $1981 \mathrm{hlm}$. 17). Segala macam modernisasi terjadi di Jepang tidak

${ }^{1}$ Penulis adalah mahasiswa Departemen Pendidikan Sejarah, Fakultas Pendidikan Ilmu Pengetahuan Sosial, Universitas Pendidikan Indonesia. Agus Mulyana (Pembimbing I) dan Leli Yulifar (Pembimbing II). Penulis dapat dihubungi melalui nomor 087822894263/email : ginanjarsetia22@gmail.com 
terkecuali pada bidang politik, ekonomi dan sosial. Industrialisasi menjadi tema penting Jepang pada masa ini.

Perubahan-perubahan yang diadakan oleh generasi muda tahun 1868 telah membuat Negeri Matahari Terbit berkembang dengan cepat kearah negara yang modern. Perkembangan ekonomi pesat seperti ini menimbulkan gairah semangat nasionalisme yang terlampau tinggi bagi orang-orang Jepang yang pada akhirnya berkeinginan tampil sebagai bangsa kuat di dunia dan sebagai dampaknya lahirlah semangat militerisme Jepang. Pada akhirnya tindakan-tindakan penyerangan sukses tersebut memicu sebuah peristiwa yang lebih besar yaitu Perang Pasifik sebagai bagian dari Perang Dunia II, yang dimulai ketika Jepang menyerang pangkalan Angkatan Laut Amerika Serikat di Pearl Harbor tahun 1941 yang pada akhirnya menjadi sebuah tindakan paling ceroboh yang dilakukan Jepang sepanjang sejarahnnya.

Setelah mengalami serentetan kemenangan antara 1941 hingga 1944, Jepang mengalami kekalahan beruntun pada tahun 1944 ketika Amerika Serikat bergabung dengan Sekutu dan menjadi musuh utama Jepang, hingga pada akhirnya tanggal 14 Agustus 1945 secara resmi Kekaisaran Jepang telah menyerah tanpa syarat kepada pasukan Sekutu. Hal ini dikarenakan kekalahan Jepang dalam Perang Dunia II yang diakhiri dengan serangan bom atom Amerika Serikat ke kota Hiroshima dan Nagasaki. Setelah sebelumnya Jepang telah menerima isi dari Deklarasi Potsdam sebagai bentuk konsekuensi dari kekalahannya dalam Perang Dunia II.

Pendudukan Amerika Serikat di Jepang hanya tinggal menunggu waktu saja, sampai akhirnya 150 personel pasukan
Sekutu tiba di Atsugi, Prefektur Kanagawa tanggal 28 Agustus 1945. MacArthur memegang otoritas sebagai pemimpin di Jepang pada masa pendudukan Sekutu, sebelumnya Sekutu telah merencanakan tugas yang akan dilakukan oleh SCAP di Jepang. SCAP hanya memiliki kewenangan pada pulau-pulau utama Jepang saja (Honshu, Hokkaido, Shikoku dan Kyushu). Kedudukan Kaisar Hirohito bahkan dapat dikatakan sekarang di bawah otoritas MacArthur.

Meskipundemikian,menjadipemimpin Jepang saat pasca Perang Dunia II bukanlah hal yang patut disyukuri. Keadaan Jepang pasca perang benar-benar kacau, banyak bangunan dan juga infrastruktur rusak berat bahkan rata dengan tanah terkena bom-bom Amerika. Selain kerusakan fisik, rakyat Jepang dihadapkan dengan kerusakan moril, krisis keyakinan dan kehilangan harapan (Manchester, 1994 hlm. 156-157), otomatis hal ini sangat berdampak kepada kegiatan politik dan ekonomi sebagai penunjang sebuah sistem kehidupan masyarakat. Tidak adanya aktivitas tersebut berarti roda kehidupan mereka pun juga ikut terhenti.

Produksi pangan yang tadinya bisa dipertahankan pada tingkat yang relatif agak tinggi, sekalipun dalam keadaan kekurangan tenaga manusia dan pupuk, dalam tahun 1945 turun sekitar 30\%. Akibatnya pada akhir tahun itu timbul krisis pangan yang berlangsung sampai awal pertama tahun 1946. Sebagai panglima tertinggi di Jepang, Jenderal MacArthur dihadapkan dengan situasi yang amat mengenaskan yang dapat terjadi pada sebuah negara. Ia harus sesegera mungkin mengeluarkan kebijakan yang akan memulihkan sistem kehidupan masyarakat Jepang. 


\section{Ginanjar Setia Mulyana, Agus Mulyana \\ KAISAR AMERIKA DI NEGERI SAKURA : PERANAN DOUGLAS MACARTHUR DALAM REKONSTRUKSI JEPANG PASCA PERANG DUNIA II}

Berdasarkan pemaparan diatas, penulis tertarik untuk mengkaji mengenai peranan Jenderal Douglas MacArthur dalam reformasi politik dan ekonomi Jepang. Karena terdapat alasan-alasan menarik dalam tema penelitian ini. Pertama, sikap Jenderal MacArthur sebagai panglima tertinggi di Jepang yang merupakan musuhnya pada masa Perang Dunia II tidak menunjukkan sikap superioritas dan tidak pula menunjukkan hasrat eksploitasi terhadap tanah musuhnya itu. Kedua, di Jepang yang keadaannya sudah kacau baik secara fisik maupun secara psikis pada saat kepemimpinan Jenderal Douglas MacArthur, mengharuskan ia untuk menjadi seorang penyelamat yang mampu mengangkat sebuah negara yang hampir hancur harapannya menjadi bangkit kembali setelah kalah perang. Ketiga, hubungan unik antara Jenderal MacArthur dan kaisar Jepang, Hirohito, dalam usaha untuk membangkitkan kembali Jepang merupakan sebuah contoh sikap yang baik antara pihak yang menang dan pihak yang kalah yang pada akhirnya saling menguntungkan keduanya.

\section{METODE PENELITIAN}

Penelitian ini menggunakan metode sejarah guna mengkaji berbagai permsalahan yang bedasarkan kurun waktu yang telah ditetapkan yaitu 19451951. Metode sejarah merupakan suatu cara yang digunakan untuk mengkaji suatu peristiwa, toko atau permasalahan yang dianggap layak dan penting yang terjadi pada masa lampau secara desriptif, kritis dan analitis. Penulisan sejarah tidak hanya mengungkapkan peristiwa secara kronologis, lebih dari itu, perlu adanya kajian dan analisis tajam yang didukung dengan konsep maupun teori yang relevan.

Pendapat lain dari Gottschalk (1986, hlm. 12) bahwa terdapat langkahlangkah penelitian mengacu pada proses metodologi penelitian sejarah yang mengandung empat langkah penting, yaitu heuristik, kritik, interpretasi dan historiografi. Dalam tahapan heuristik penulis menggunakan teknik-teknik guna mempermudah pencarian sumber dengan teknik yang digunakan yaitu studi literatur. Setelah mengumpulkan berbagai sumber, tahap selanjutnya adalah melakukan kritik terhadap setiap sumber literatur yang tersebut. Adanya sumber sejarah tidak mendorong peneliti percaya begitu saja untuk dijadikan referensi, tetapi peneliti melakukan tahapan kritik terlebih dahulu. Untuk itu, sejarawan harus mengarahkan pikiran, bahkan seringkali sejarawan harus menggabungkan antara pengetahuan, sikap ragu, percaya begitu saja, meggunakan akal sehat, dan melakukan tebakan. Hal itu senada dengan pendapat Sjamsuddin (2012, hlm. 104) mengemukakan bahwa kritik menyangkut verifikasi pengujian mengenai kebenaran atau ketepatan (akurasi) dari sebuah sumber, yang kemudian dikenal dengan cara melakukan kritik eksternal dan internal.

Langkah selanjutnya setelah dilakukan kritik adalah tahap interpretasi yang disertai dengan menggunakan beberapa pendekatan menggunakan bantuan ilmu sosial lain yaitu sosiologi, ekonomi dan politik. Interpretasi dilakukan dengan pendekatan interdisipliner guna menyusun dan menganalisis berbagai informasi yang telah diperoleh. Tahap terakhir yaitu historiografi dengan memperhatikan aturan penulisan. 


\section{HASIL PENELITIAN DAN PEMBAHASAN}

Sebelum Jepang terlibat Perang Dunia II, Jepang mengalami sebuah restorasi yang mengubah Jepang secara utuh dari segi politik, ekonomi, sosial dan budaya, yaitu Restorasi Meiji pada tahun 1868. Sebelumnya Jepang adalah sebuah daerah yang terisolasi sebagai akibat dari politik sakoku-rei yang diberlakukan oleh pemerintahan shogun Tokugawa (16001868) yang menjadi penguasa Jepang pada saat itu. Namun setelah Restorasi Meiji diberlakukan, Jepang mulai mengubah diri menjadi negara yang lebih terbuka kepada perkembangan zaman dengan berkiblat kepada bangsa-bangsa Barat yang memang merupakan bangsa yang paling maju dalam segi politik dan ekonomi pada akhir abad ke-19.

Perubahan besar dalam sistem politik Jepang ini adalah dengan adanya sistem pemerintahan baru yang bersifat oligarki dikarenakan kekuasaan dipegang oleh sekelompok elit seperti keluarga Satsuma dan Chosu yang masih merupakan bekas klan samurai pada masa keshogunan. Selain itu, pemerintah juga mengizinkan masyarakat untuk bebas berpolitik, tidak terbatas pada klan tertentu saja. Adanya kebebasan berpolitik ini memicu dibentuknya partai-partai politik dengan ideologi yang beragam, tercatat terdapat 3 partai yang terbentuk tidak lama setelah Restorasi Meiji yaitu partai Liberal (Jiyuto), partai Reformasi (Kaishinto) dan partai Konstitusi Kekaisaran (Teiseito) namun kekuatan dari partai-partai politik tersebut tidak dapat dikatakan kuat karena selain Jepang baru mengadopsi sistem tersebut juga prisnsip dan dasar partai tersebut masih samar (Clyde dan Beers, 1966 hlm. 136). Partai-partai politik
Jepang awal lebih seperti kumpulan orang kaya yang merupakan kerabat atau keluarga mengikuti pemimpin partai tersebut dibandingkan sebuah organisasi terstruktur yang memiliki kesamaan prinsip pada setiap anggotanya.

Namun demikian, kekuatan partai politik kalah jauh pada saat itu dibandingkan dengan kementrian pertahanan yang dikenal dengan gunbatsu yang artinya adalah diktator militer. Tidak ada seorangpun yang berani menentang gunbatsu, 50\% dari anggaran belanja negara diambil oleh gunbatsu untuk memperkuat angkatan perang, hal ini merupakan salahsatu dampak industrialisasi yang sedang dilakukan oleh Jepang (Soebantardjo, 1961 hlm. 12).

Kekuasaan militer gunbatsu ini mempengaruhi ideologi negara menjadi berhaluan militeris ditandai dengan lahirnya doktrin Fukoku Kyohei. Semangat perubahan masyarakat Jepang sangat dipengaruhi oleh keberhasilan dalam bidang perindustrian. Untuk lebih mengembangkan kemajuan dalam infrastruktur yang pada akhirnya berdampak pada pembangunan ekonomi dan industri, pemerintah Jepang mengambil beberapa langkah untuk mengerahkan ekonomi sesuai dengan harapan. Salahsatunya adalah dengan banyak mendatangkan teknisi-teknisi ahli dari luar negeri dan mengirimkan mahasiswa-mahasiswa ke luar negeri untuk mempelajari dan mengamati teknologi Barat yang pada akhirnya mereka akan kembali pulang untuk mengimplementasikan apa yang mereka pelajari selama kuliah di luar negeri.

Kemajuan pesat yang dialami oleh Jepang ditambah dengan doktrin ultranasionalisme dimanfaatkan oleh 


\section{Ginanjar Setia Mulyana, Agus Mulyana \\ KAISAR AMERIKA DI NEGERI SAKURA : PERANAN DOUGLAS MACARTHUR DALAM REKONSTRUKSI JEPANG PASCA PERANG DUNIA II}

perusahaan-perusahaan swasta gabungan yang disebut dengan zaibatsu, mereka melihat kebangkitan Jepang sebagai pintu untuk memperlebar sayap bisnis mereka. Zaibatsu mulai memberikan pengaruh yang besar pada perekonomian Jepang di akhir periode 1930an, mereka mengontrol perusahaan-perusahaan keuangan, pertambangan, industri, dan sektor ekonomi modern lainnya (Nakamura, 1985 hlm. 2). Kemudian selanjutnya zaibatsu-zaibatsu ini mulai bergerak ke sektor industri berat, mengambil alih perusahaan yang mengalami kerugian hebat dan menggunakan shogo sosha (holding companies) untuk memperluas penguasaan terhadap lebih banyak lagi perusahaan melalui cara kepemilikan bersama. Pemerintah tidak sedikit pun mengambil tindakan untuk mengurangi kekuatan ekonomi zaibatsu, merangsang pertumbuhan mereka dengan memberikan subsidi, melindungi tarif, menyetujui gabungan perusahaan yang memonopoli harga dan produksi (kartel), dan tindakan lainnya yang dirancang untuk mendorong ekspansi kegiatan zaibatsu ke dalam industri berat.

Dapat dilihat bahwa Jepang saat itu memiliki beberapa motivasi besar untuk melakukan ekspansi. Pertama, perkembangan insdustri pesat membuat Jepang membutuhkan banyak bahan mentah dalam jumlah besar, Jepang tidak dapat hanya mengandalkan sumber dari dalam negeri. Kedua, dorongan zaibatsu untuk memperluas sayap bisnis mereka, kekuasaan zaibatsu dapat dikatakan sangat besar mengingat pemilik perusahaanperusahaan tersebut juga adalah keluarga orang-orang pemerintahan Jepang. Dan yang terakhir adalah doktrin militerisme kuat yang menyebabkan Jepang memiliki persenjataan yang cukup membuat percaya diri untuk melakukan ekspansi militer.

Pada tahun 1937 sebagai puncak dari militerisme Jepang melakukan invasi ke Tiongkok, tentara di Guangdong dengan dorongan keberhasilannya di Manchuria memperluas medan perangnya dari Tiongkok Utara ke Tiongkok Tengah kemudian Selatan. Penyerangan atas Tiongkok dianggap sebuah pelanggaran karena Jepang tidak melakukan peringatan sebelumnya, perang yang tidak dinyatakan ini disebut dengan Nisshi Jihen atau insiden Tiongkok (Chang, $2009 \mathrm{hlm}$. 4-5). Krisis dengan Tiongkok merupakan langkah pertama Jepang dalam misinya menguasai Asia. Keberhasilan terus menerus mendorong Jepang untuk terus menggenjot perindustrian untuk kebutuhan militer.

Pada Desember 1941 dengan kondisi politik yang begitu kaku dan otoriter dibawah kepemimpinan Hideki Tojo, Jepang mulai memasuki gerbang Perang Dunia II di teater Perang Pasifik ditandai dengan penyerangan terhadap pangkalan militer Amerika Serikat di Pearl Harbor, Kepulauan Hawaii. Akibat dari kekuasaan yang begitu besar dari pihak militer, kekuatan yang berkuasa dalam pemerintahan Jepang hanya berada pada Rikugun (Angkatan Darat), Kaigun (Angkatan Laut) dan tentunya, Kaisar Hirohito, namun kaisar tidak banyak diberikan peran untuk menentukan arah politik Jepang. Selama periode 1941 hingga 1943, tentara Kekaisaran Jepang mengalami apa yang dinamkan "penyakit kemenangan" yang mengakibatkan Jepang jumawa hingga menolak pengajuan damai yang diajukan oleh Sekutu pada tahun 1942 dengan mengeluarkan kebijakan anti-negosiasi perang. 
Titik balik Jepang dalam Perang Dunia II terjadi pada tahun 1944 hingga 1945, Jepang mulai mengalami kekalahan beruntun setelah Amerika Serikat mulai aktif dalam Perang Pasifik. Pada tahun 1944, banyak sekolah di Jepang mulai ditutup dan digunakan sebagai pabrik untuk memproduksi kebutuhan perang. Industri lokal tidak mampu untuk memenuhi permintaan produksi yang sangat tinggi dan terancam mengalami kebangkrutan. Bukan hanya dalam sektor industri, ekonomi maritim yang menjadi kebutuhan banyak orang di Jepang mengalami kemunduran yang diakibatkan banyaknya kapal nelayan Jepang yang rusak diserang musuh dan tidak dapat diperbaiki karena mekanik dipekerjakan untuk membuat kapal-kapal perang baru.

Di penghujung perang tahun 1945, situasi sulit ini menjadi salahsatu faktor kekalahan Jepang dalam Perang Dunia II, kondisi memperihatinkan ini diperparah dengan kerusakan yang ditimbulkan oleh perang yang mengakibatkan Jepang mengalami inflasi tinggi dan devaluasi nilai mata uang. Infrastruktur yang digunakan sebagai alat produksi banyak mengalami kerusakan parah sehingga perekonomian Jepang terancam terhenti total mengalami stagnasi yang panjang.

Jepang menyerah kepada Sekutu pada tanggal 15 Agustus 1945, ditandai dengan siaran suara Kaisar Hirohito kepada masyarakat Jepang mengenai penyerahan diri Jepang dengan tanpa syarat kepada Sekutu. Pendudukan Sekutu di Jepng hanya tinggal menunggu waktu saja. Meskipun pendudukan Jepang dilakkan atas nama Sekutu, pada nyatanya hanya Amerika Serikat yang melakukan pendudukan di Jepang. Faktor - faktor yang melatarbelakangi pendudukan
Amerika Serikat di Jepang dibagi kedalam faktor internal dan eksternal. Dalam hal ini faktor internal adalah faktor yang berasal dari pihak Sekutu sendiri untuk melakukan pendudukan terhadap Jepang yang dirundingkan pada beberapa konferensi hingga menghasilkan Deklarasi Potsdam dan faktor eksternal adalah faktor yang berasal dari luar, dalam hal ini adalah perseteruan Amerika Serikat dengan Uni Soviet yang diakibatkan oleh sikap politik Uni Soviet di Eropa yang tanpa melalui perundingan langsung melakukan pendudukan serta penyebaran paham komunis terhadap negara-negara di Eropa Timur.

Truman yang merasa dikhianati oleh Uni Soviet ingin melakukan hal yang sama setelah ia melihat kesempatan besar di wilayah Asia, mengingat peran besar Amerika Serikat di wilayah ini pada Perang Dunia II, akan tetapi tentara Soviet juga menginginkan wilayah ini. Segera setelah Jepang menyerah Truman melakukan lobi kepada negara-negara anggota Sekutu lain dan pihak pengadilan perang untuk meminta Amerika Serikat memiliki kekuasaan penuh di Jepang.

Segera setelah penyerahan diri Jepang tanggal 15 Agustus 1945 ditandai dengan pernyataan resmi penyerahan tanpa syarat Jepang oleh kaisar Hirohito di radio atau disebut Gyokuon-hoso. Pada hari yang sama presiden Harry S. Truman menunjuk Jenderal Douglas MacArthur sebagai Supreme Commander for the Allied Powers atau disingkat SCAP, untuk menjadi pemimpin bagi seluruh wilayah yang diduduki oleh Amerika Serikat yaitu seluruh pulau utama Jepang, kepulauan Okinawa, kepulauan Amami dan kepulauan Ogaswara. 


\section{Ginanjar Setia Mulyana, Agus Mulyana \\ KAISAR AMERIKA DI NEGERI SAKURA : PERANAN DOUGLAS MACARTHUR DALAM REKONSTRUKSI JEPANG PASCA PERANG DUNIA II}

Tujuan dari pembentukan SCAP ini sejatinya adalah untuk melucuti serta memulangkan tentara-tentara Jepang yang berada di luar Jepang. Namun, Truman menginginkan kekuasaan Amerika atas Jepang secara mutlak dengan memiliki pemimpin yang loyal kepada Amerika Serikat seperti Soviet kepada negaranegara bonekanya.

MacArthur yang diberi kekuasaan mutlak di Jepang, bahkan melebihi kaisar Jepang sendiri, tidak begitu saja menerima keinginan Truman. Bagi MacArthur, pengaruh yang benar-benar kuat didasari atas kepercayaan, bukan rasa takut. Meskipun dalam hatinya MacArthur tidak begitu peduli dengan keinginan Truman, namun apayang dilakukan MacArthur pada dasarnya akan menghasilkan beberapa hal yang diinginkan oleh presiden Amerika Serikat itu.

Menjadi pemimpin Jepang pascaPerang Dunia II bukanlah hal yang patut disyukuri, bahkan mungkin itu adalah ujian. Sebelum kejadian penyerangan Pearl Harbor tahun 1941, Jepang telah disebut sebagai "Pabriknya Asia". Kini negeri itu merupakan timbunan sampah dan puing-puing bangunan yang berserakan di pinggir jalan, kekaisaran Hirohito teleh diciutkan sampai 81\%, dari $773.781 \mathrm{mil}$ persegi menjadi hanya 146.690 mil persegi (Manchester, 1994 hlm. 155).

Sejumlah besar orang Jepang kehilangan pekerjaannya dikarenakan pabrik-pabrik banyak yang hancur terkena bom. Sebelumnya, dalam upaya mendukung perang 80\% mesin-mesin tekstilnya telah diubah untuk maksudmaksud lain, kini sisa mesin-mesin itu berserakan di puing-puing bangunan yang hancur dibom. Keadaan lebih buruk terdapat di kota Hiroshima dan Nagasaki yang hancur terkena bom atom, sebagian besar sisanya berupa abu dan puing-puing berwarna hitam. Orang-orang tinggal di dalam gubug-gubug dan pondok yang dibuat dari lembaran-lembaran besi yang bengkok, mereka tidak mempunyai tempat berteduh lainnya. Lebih dari 2 juta rumah telah hancur oleh pasukan udara LeMay. Hal ini akan diperburuk dengan hampir 7 juta prajurit Jepang yang ditempatkan di Tiongkok, Korea, Indocina Prancis, Malaya dan wilayah-wilayah jauh lainnya akan segera mengalami demobilisasi dan dipulangkan ke tanah air mereka. Setelah mereka kembali, disertai dengan penduduk sipil, Jepang akan membutuhkan sekurang-kurangnya 4 juta rumah baru, dan rakyat harus makan (James, 1985 hlm. 254). Pemandangan tersebut menjadi sambutan ketika Douglas MacArthur menginjakkan kakinya ke Jepang, ia langsung mendirikan dapurdapur tentara dan mengirimkan berita ke Washington bahwa ia membutuhkan 3,5 ton pangan dengan segera, permintaan MacArthur ditanggapi dengan ragu-ragu oleh Pentagon dan meminta MacArthur memberikan segala detail atas segala permintaannya lalu pada akhirnya ditolak.

MacArthur telah menduga bahwa permintaannya tersebut akan ditolak oleh Pentagon karena sebelumnya pula saat ia ditunjuk sebagai SCAP untuk memegang komando dalam operasi pendudukan Jepang, MacArthur tidak berpikir orang seperti Truman akan menepati janjijanjinya dalam Deklarasi Potsdam. MacArthur berpikir bahwa Truman membuat pernyataan yang bersifat tidak akan menyiksa Jepang hanya sebagai alat untuk membuat Jepang menyerah dengan 
segera sebelum Uni Soviet mempersiapkan diri untuk melakukan ekspansi ke Timur, Truman hanya peduli dengan tujuannya (Imparato, 2001 hlm. 244). Dengan kata lain jika MacArthur akan melakukan pendudukan dengan cara yang disebutkan dalam Deklarasi Potsdam, ia tidak akan mendapatkan dukungan dari presiden Amerika Serikat itu.

Penduduk Jepang bukan hanya terpuruk secara fisik dimana mereka tidak mempunyai tempat untuk ditinggali atau tidak mempunyai pekerjaan untuk dilakukan, namun juga terpuruk secara batin, merasa terhina dan terpukul dengan pernyataan menyerah yang diucapkan sendiri oleh kaisar yang selama ratusan tahun dianggap sebagai dewa kepada mereka. Masa depan mereka bergantung kepada apa saja yang mengalir kedalam kondisi kehilangan harapan yang mereka alami. Dengan kata lain masa depan masyarakatJepang akan sangatbergantung kepada orang yang memerintah mereka dan membawa ke arah mana Jepang selanjutnya pergi.

MacArthur berpikir jika penduduk Jepang memiliki kepribadian yang unik, berbeda dengan kebanyakan orangorang Barat, penduduk Jepang adalah masyarakat yang dibentuk oleh tradisi, mereka dikuasai oleh perasaan (Manchester, 1994 hlm. 157). Pendudukan yang membuat penduduk Jepang merasa sangat terpukul, ketika mereka melihat wujud dewa yang mereka puja harus bertekuk lutut kepada bangsa asing dan ketika mereka pertama kali mendengar suara kaisar, mereka harus mendengarkan pernyataan menyerah dari dewa mereka. Hal ini membuat MacArthur menilai jika tetap membuat bangsa Jepang merasa terhina, maka akan mustahil untuk membangun Jepang kembali seperti semula (Imparato, 2001 hlm. 250). Dengan kata lain, jika ingin menyelamatkan Jepang, MacArthur harus melakukan yang akan membuatnya dibenci oleh pihak Barat, yaitu menyelamatkan Kaisar Hirohito dari pengadilan perang. Dengan cara ini masyarakat Jepang tidak akan merasa terhina dan akan membuat rekonstruksi Jepang menjadi lebih mudah. Namun MacArthur tidak terburu-buru untuk memerintahkan kaisar segera bertemu dengannya, ia menolak segala saran yang dinilai akan mencerminkan bahwa dirinya adalah penguasa sebenarnya di Jepang pada saat itu.

Bersama sekretaris militernya, Brigjen Bonner F. Fellers, MacArthur berusaha mengumpulkan pejabat-pejabat serta perwira militer Jepang untuk mendapatkan bukti dan data bahwa Hirohito bukan merupakan otak dari Jepang selama Perang Dunia II. Potensi disintegrasi yang dapat terjadi apabila Hirohito dijadikan penjahat perang adalah berupa revolusi yang dapat mempersulit masa pendudukan dan Amerika Serikat akan membutuhkan lebih banyak pasukan untuk ditugaskan di Jepang atau masuknya paham komunis ke Jepang dari Tiongkok yang dikuasai Soviet, tentu Truman tidak menginginkan hal itu terjadi.

Dengan keputusan penyelamatan kaisar tersebut mendapatkan dukungan dari Truman, MacArthur dan Fellers berpandangan bahwa Hideki Tojo dan pemimpin militer Jepanglah yang layak disalahkan atas memulai perang sejak insiden Mukden dengan Tiongkok tahun 1931 ataupun pertanggung jawaban atas penyerangan Pearl Harbor. 


\section{Ginanjar Setia Mulyana, Agus Mulyana \\ KAISAR AMERIKA DI NEGERI SAKURA : PERANAN DOUGLAS MACARTHUR DALAM REKONSTRUKSI JEPANG PASCA PERANG DUNIA II}

Tojo dalam testimoni nya saat International Military Tribunal for the far East atau disebut juga Pengadilan Tokyo tanggal 29 April 1946 menyatakan dirinya bersalah atas kejahatan perang yang dilakukan Jepang dan memulai perang. MacArthur bertanggung jawab atas pendakwaan 4300 penjahat perang Jepang, lebih dari 1000 orang dihukum mati, dan ratusan lainnya dipenjara seumur hidup (Drea, 2007 hlm. 7). Percobaan melindungi kaisar oleh MacArthur berhasil, kaisar dan keluarganya, pangeran Chichibu, Asaka, Takeda, Higashikuni dan Fushimi dinyatakan tidak bersalah oleh pengadilan berdasarkan bukti-bukti yang telah dikumpulkan bahwa Hirohito sejak awal telah memperingatkan pihak militer agar berhati-hati jika bertindak dan atas peranannya mengakhiri perang (Dower, 1999 hlm. 323). MacArthur membantah rumoryang beredar oleh media sebelumnya jika kaisar akan turun tahta.

Setelah menyelamatkan kaisar Jepang, kini MacArthur dihadapkan dengan kondisi politik dan ekonomi Jepang yang hancur lebur. Terlebih lagi pada bidang ekonomi. Namun, reformasi ekonomi akan sukar dilakukan jika organisasi serta instansi dalam pemerintahannya saja belum beres. Maka dari itu MacArthur memutuskan untuk melakukan perubahan-perubahan pada sistem politik Jepang tereblih dahulu. Melihat dunia perpolitikan Jepang yang begitu kaku dan didominasi oleh keluarga tertentu, MacArthur membuat perubahan untuk lebih membuka pintu demokrasi bagi Jepang, Anggota-anggota pemerintahan harus dipilih melalui pemilihan umum.

Selain itu ia juga membuka pintu bagi liberalisme masuk ke Jepang, ia membuktikannya dengan memperbolehkan kaum wanita untuk menjadi setara kedudukannya dengan kaum pria. Wanita boleh berpolitik serta memberikan aspirasinya. Wajah Jepang berubah total pada awal 1946, kebijakan-kebijakan MacArthur mampu membuat Jepang yang dahulu kaku dan sangat militeris menjadi Jepang yang liberal. Tindak lanjut MacArthur untuk mengimplementasikan Undang-undang kebebasan bagi Jepang adalah dengan melaksanakan Pemilihan Umum pertama seusai perang, dalam buku Mifflin James berjudul The Years of MacArthur : 19451964 Triumph and Disaster (1985 hlm. 356) MacArthur menilai jika omong kosong apabila semua undang-undang baru yang ia terapkan tidak dilaksanakan oleh perangkat dan anggota pemerintahan yang baru pula. MacArthur menginginkan Pemilihan Umum yang lebih demokratis dari sebelumnya.

Setelah melaksanakan Pemilihan Umum yang baru tanggal 19 April 1946, dengan perangkat pemerintahan yang dipilih langsung oleh rakyat Jepang. MacArthur berencana untuk membuat kebijakan-kebijakan demokrasi dan liberalnya sah secara hukum. Dengan kata lain ia harus mengubah konstitusi negara tersebut. Bersama dengan Perdana Menteri baru Jepang, Shigeru Yoshida, Douglas MacArthur menyusun kembali Konstitusi Jepang agar sesuai dengan misi nya untuk membuat Jepang lebih demokratis dan liberal. Sebelumnya Jepang mengadopsi undang-undang dasar yang disusun pada saat Restorasi Meiji tahun 1868 yaitu Konstitusi Meiji. Konstitusi Meiji bersifat monarki konstitusi, sebagaimana kaisar merupakan kepala negara dan perdana menteri merupakan kepala pemerintahan (Hunt, 1977 hlm. 183). Namun Konstitusi Meiji masih belum bersifat demokratis, 
Perdana Menteri dipilih oleh Dewan Pertimbangan Agung, bukan oleh rakyat seperti yang MacArthur kehendaki.

Adapun hal-hal yang diubah atau ditambahkan oleh MacArthur adalah pasal-pasal mengenai Hak Azasi Manusia, kesetaraan gender, kebebasan berpendapat dan juga otonomi daerah. Hal tersebut dilakukan demi mewujudkan Jepang yang bebas dari pengekangan oleh aturan mereka sendiri. Pihak Jepang secara tidak terduga bersifat kooperatif dengan rencana-rencana MacArthur yang memang sangat konstruktif.

Konstitusi 1947 tersebut diserahkan kepada kaisar Hirohito untuk ditinjau, kemudian konstitusi baru itu dikirimkan kembali kepada Dewan Pertimbangan Agung untuk disetujui dan kepada Kaisar kembali untuk direstui. Akhirnya konstitusi itu diterima dengan baik pada tanggal 3 November 1946 dan mulai berlaku secara efektif tapat enam bulan kemudian tanggal 3 Mei 1947.

Kebijakan demokratisasi dan Liberalisasi MacArthur juga bukan hanya berlaku bagi politik Jepang saja, namun juga bagi perekonomian Jepang. Pada akhir tahun 1947, MacArthur mengalihkan perhatiannya dari reformasi di bidang politik ke bidang ekonomi. Ada beberapa masalah perekonomian yang muncul setelah kekalahan Jepang dalam Perang Dunia II, yang pertama adalah pengangguran. Pada saat itu, kekuatan militer dibubarkan dengan jumlah pasukan yang ada sekitar 7 juta orang (Bix, 2000 hlm. 619). Penghentian produksi untuk keperluan militer mengakibatkan 4 juta tenaga kerja, 750 ribu diantaranya adalah wanita, dan terdapat sekitar 1,5 juta orang Jepang yang bermukim di wilayah luar Jepang kembali ke Jepang, keadaan tersebut mengakibatkan jumlah pengangguran di Jepang meingkat drastis hingga berjumlah 13 juta orang.

MacArthur masih melihat unsur-unsur feodalisme dalam sistem perekonomian Jepang, bukan hanya pada ekonomi agraris melainkan juga ekonomi industri. Pada sektor ekonomi agraris, para petani buruh tidak mendapatkan upah yang cukup dari para pemilik tanah serta petani buruh lebih cenderung semakin miskin dan pemilik tanah semakin kaya, maka dilakukan reformasi agraria (Noichi Kaikaku) yakni dengan pemerintah membeli tanah dari tuan tanah dan akhirnya dijual kembali dengan harga murah kepada petani buruh, hal itu dapat meningkatkan peroduksi pangan Jepang dan bukan hanya mampu mensejahterakan kehidupan petani dan juga membuat hasil pertanian membantu rakyat Jepang yang kelaparan.

Feodalisme juga terdapat pada sektor ekonomi industri, industri Jepang sebelumnya berada di bawah pengasaan gabungan zaibatsu yang mendapat hak dan perlakuan khusus dari pemerintah Jepang (Nakamura, 1985 hlm 24.). Tujuan penguasaan industri tersebut untuk mempertahankan dan melanjutkan hubungan semifeodal antara tenaga kerja dan sistem manajemen. Hal tersebut dilakukan dengan cara menekan para pekerja dengan upah yang rendah, mencegah perkembangan serikat pekerja, menghalangi kebebasan suatu perusahaan yang potensial, dan menghalangi kebangkitan kelas menengah di Jepang.

Perbuatan-perbuatan zaibatsu tersebut sangat betentangan keras dengan tujuan perubahan yang dibawa oleh MacArthur. Langkah besar yang ia harus lakukan 


\section{Ginanjar Setia Mulyana, Agus Mulyana \\ KAISAR AMERIKA DI NEGERI SAKURA : PERANAN DOUGLAS MACARTHUR DALAM REKONSTRUKSI JEPANG PASCA PERANG DUNIA II}

adalah dengan membubarkan perusahaanperusahaan zaibatsu tersebut. MacArthur melihat pentingnya zaibatsu bagi kaum militer Jepang, zaibatsu turut berperan dalam membiayai perang dan memajukan industri persenjataan Jepang. Monopoli yang dilakukan oleh zaibatsu dianggap dapat menghambat kebijakan demokrasi ekonomi. Tujuan utama pembubaran zaibatsu adalah untuk menghentikan dukungan mereka kepada pihak militer dan juga untuk membuat perekonomian Jepang lebih demokratis tanpa adanya pihak lain yang menghalang-halangi kebebasan ekonomi. Langkah awal yang dilakukan dalam pemecahan zaibatsu adalah memecah perusahaan induk yang menjadi inti zaibatsu dengan menjual saham-saham perusahaan induk tersebut kepada publik dan perorangan. Pada tahun 1946 perusahaan induk tersebut mempunyai 167 juta lembar saham yang bernilai kurang lebih 8,1 miliar Yen (Nakamura, 1985 hlm. 35).

Langkah berikutnya adalah dengan melakukan penghapusan dan pemecahan konsentrasi ekonomi seperti hak milik dan aset milik zaibatsu. Tujuan dari pemecahan konsentrasi besar kekuatan bisnis ini adalah untuk memberikan kesempatan bagi industri perusahaan yang baru untuk berkompetisi dan bersaing secara sehat tanpa tekanan dari zaibatsu. Tahun 1947, 16 perusahaan zaibatsu menjadi target pemecahan dan penghapusan aset, dan 26 lainnya menjadi target reorganisasi setelah dilakukanpemecahan, diantaraperusahaan tersebut adalah Asano, Furukawa, Nakajima, Nissan, Nomura dan Okura. Sementara itu, Yasuda, salahsatu anggota zaibatsu Big Four, membubarkan diri pada tahun 1946. Asetyang dimilikioleh keluarga pemilik zaibatsu dibekukan, perusahaan- perusahaan kecil milik zaibatsu tersebut pun dibubarkan, dan praktik interlocking directorship, yang zaibatsu gunakan untuk berkoordinasi menghalangi perusahaan baru yang berkembang, dilarang dan dianggap melanggar hukum. Di lain pihak, zaibatsu Matsushita, tidak dibubarkan karena diselamatkan oleh petisi yang ditandatangani oleh 15.000 orang pekerja beserta keluarganya (Morck \& Nakamura, 2005 hlm. 33).

Menyusul pembubaran zaibatsu, MacArthur memperbaiki aturan-aturan yang dahulu dibentuk oleh zaibatsu. Hal ini ditandai dengan reformasi tenaga kerja, hal ini dilakukan demi memperbanyak lapangan pekerjaan yang berpengaruh pada penurunan jumlah pengangguran yang begitu banyak. Selain itu, pembubaran zaibatsu berdampak pada munculnya perusahaan-perusahaan baru yang membuka lapangan pekerjaan baru.

Untuk menangani inflasi, MacArthur mencontoh kebijakan pemerintah Jepang pada masa Meiji dengan mendatangkan ahli-ahli keuangan dari luar negeri, khsusnya Amerika Serikat. Kebijakan ini meliputi pembentukan Bank Rekonstruksi untuk menekan inflasi serta menentukan nilai tukar tetap Yen terhadap Dollar Amerika selama waktu pendudukan. Selain inflasi, sistem perpajakan juga mengalami reformasi. Reformasi sistem perpajakan tersebut lebih menekankan pada pajak penghasilan dan pajak perusahaan untuk membantu peningkatan pendapatan negara dan stabilitas perekonomian tanpa harus menyulitkan masyarakat.

Dampak dari kebijakan reformasi politik dan ekonomi Jepang oleh Douglas MacArthur membuat Jepang terbebas dari pengekangan yang dilakukan oleh 
aturan-aturan mereka sendiri. Jepang menjadi negara liberal yang memadukan aspek tradisi serta aspek modern. Dua hal yang sangat sulit untuk bersatu, namun nyatanya reformasi MacArthur berhasil membentuk Jepang serta membangkitkan Jepang yang hancur setelah perang hingga Jepang yang maju dalam kurun waktu 6 tahun saja antara tahun 1945 hingga 1951.

\section{SIMPULAN}

Pendudukan Jepang sangat penting bagi Amerika Serikat bukan hanya untuk menghukum negara yang kalah dalam perang dunia II dan memerintah mereka. Namun juga untuk menghadirkan sebuah negara yang demokratis dan liberal untuk berada dibelakang Amerika Serikat nantinya, mengingat hubungan dua negara adidaya Amerika Serikat dengan Uni Soviet semakin memburuk pasca Perang Dunia II. Sama pentingnya bagi Jepang, meskipun merasa sangat dipermalukan, Jepang tidak memiliki pilihan lain sebagai konsekuensi dari kalahnya mereka dalam Perang Dunia II.

Jepang membutuhkan pertolongan untuk menggerakan kembali roda perekonomian yang terhenti serta kebijakan untuk mengubah sistem politik kaku mereka yang penuh dengan norma layaknya samurai. Jika saja MacArthur tidak mengubah sistem sosial mereka yang feodalis, tidak mungkin Jepang menjadi negara industri yang dihormati seperti sekarang. Kebijakan Douglas MacArthur memiliki peranan penting dalam membuka pintu kebebasan bagi masyarakat Jepang yang dahulu dikekang oleh aturan mereka sendiri, kesetaraan gender serta kebebasan berpendapat contohnya. Restorasi Meiji mungkin berhasil memodernisasi bangsa
Jepang secara fisik, namun kebijakan MacArthur berhasil memodernisasi bangsa Jepang secara psikis.

Terdapat beberapa kunci sukses implementasi dari kebijakan politik dan ekonomi MacArthur adalah kemampuan MacArthuruntukmembacahatidan pikiran rakyat Jepang. Perasaan empati MacArthur kepada rakyatJepang membuat dia berpikir sebagai rakyat Jepang yang merasa kalah dan malu sebelum mengambil keputusan. Seperti pendapat yang dikemukakan oleh Edward O. Reischauer dalam buku Pedang Samurai dan Bunga Seruni, bahwa bangsa Jepang adalah bangsa yang dibentuk secara tradisi, MacArthur melakukan kebijakan yang sangat penting yaitu mempertahankan kedudukan kaisar Jepang, meskipun menuai kecaman dari Amerika Serikat dan dunia.

Kebijakan tersebut sangat penting karena masyarakat Jepang membutuhkan panutan spiritual mereka, mustahil bagi MacArthur untuk membangun Jepang jika rakyatnya hancur secara moral, bagi masyarakat Jepang, melayani kaisar adalah sebuah kehormatan tertinggi. Kunci sukses MacArthur selanjutnya adalah bahwa dia memerintah tanpa intervensi ataupun konsultasi dengan negara anggota Sekutu lainnya, sekalipun dari presiden Truman yang berkalikali mengecam kebijakan MacArthur, jika MacArthur harus mendapatkan persetujuan dari pihak lain, seberapa bijak apapun kebijakan MacArthur akan selalu mendapatkan kritik. Kunci sukses terakhir adalah sikap kooperatif yang tidak terduga dari pemerintah Jepang sebagai respon dari kebijakan MacArthur yang konstruktif serta mempertahankan kaisar mereka, sikap kooperatif institusi pemerintahan 


\section{Ginanjar Setia Mulyana, Agus Mulyana \\ KAISAR AMERIKA DI NEGERI SAKURA : PERANAN DOUGLAS MACARTHUR DALAM \\ REKONSTRUKSI JEPANG PASCA PERANG DUNIA II}

Jepang membuat rekonstruksi Jepang Publishing Company.

semakin mudah dilakukan.

\section{DAFTAR PUSTAKA}

Bix, H.P. (2000). Hirohito and The Making of Modern Day Japan. New York: Harper Collins Publishers.

Chang, I. (2009). The Rape of Nanking. Jakarta: Buku Kita.

Clyde, P dan Beers, F. (1966). The Far East : A History of The Western Impact and The Eastern Response (1830-1965). New Jersey: Prentince Hall. Inc.

Dower, J. (1999). Embracing Defeat: Japan in The Wake of World War II. New York: Norton Publishing.

Drea, E. (2007). Researching Japanese War Crimes Records. Washington, D.C.: Library of Congress Publishing.

Hunt, F. (1977). The Untold Story of Douglas MacArthur. Washington : Manor Books.

Imparato,E.(2001).GeneralMacArthur : Wisdom and Visions. New York: Turner
James, C. (1985). The Years of MacArthur Vol.3 : 1945-1964 Triumph and Disaster. Boston: Houghton Mifflin.

Manchester, W. (1994). MacArthur Sang Penakluk. Jakarta: Sinar Harapan

Nakamura, T. (1985). Economic Development of Modern Japan. Tokyo: International Society for Educational Information Inc.

Nakamura, T. (2005). Politics and Power of 2oth Century Japan. Tokyo: Iwanami Shoten.

Morck, R dan Nakamura, M. (2005). A Frog in a Well Knows Nothing about the Ocean : A History of Corporate Ownership in Japan. Massachusetts: NBER Books.

Rosidi, Ajip. (1981). Mengenal Jepang. Jakarta: Pusat Kebudayaan Jepang.

Sjamsuddin. (2012). Metodologi sejarah. Yogyakarta: Penerbit Ombak.

Soebantardjo. (1961). Sari Sedjarah Djilid I - Asia dan Australia. Yogyakarta: Penerbit Bopkri. 